\title{
Estimation of the Local Human Health Burden Due to Inhalation of Fine Particulate Matter and Identification of Major Emission Sources Using A Life Cycle Impact Assessment Method
}

\author{
Seung-Woo Jeong ${ }^{1,+} \cdot$ Gyu-Tae Seo ${ }^{2,++}$ \\ ${ }^{1}$ Department of Environmental Engineering, Kunsan National University, Kunsan, Korea \\ ${ }^{2}$ School of Civil, Environmental and Chemical Engineering, Changwon National University, Changwon, Korea
}

(Received April 29, 2019; Revised June 11, 2019; Accepted June 12, 2019)

Objectives: This study determined the local human health burden of fine particulate matter (PM2.5) as disability adjusted life years (DALY) for three Korean cities: Jeonju, Iksan and Changwon. Major air pollutants and emission sources contributing the local human health burden were identified by using a life cycle impact assessment (LCIA) method.

Methods: The human health burden of PM2.5 was determined by using two methods. First, the PM2.5 concentration-health response method used the concentration-response factor and severity factor for specific age groups over 30 years old and the annual average PM2.5 concentrations to determine DALY for cardiopulmonary diseases and lung cancer. Second, the LCIA used the intake fraction, the effect factor and the local air pollutant emission to quantify DALY due to inhalation of primary and secondary PM2.5.

Results and Discussion: The human health burden of PM2.5 (DALY/1000 capita) of Jeonju, Iksan and Changwon was respectively determined as $25.44,35.03$ and 22.24 by the PM2.5 concentration-health response method. The LCIA resulted in the human health burden (DALY/1000 capita) of Jeonju, Iksan and Changwon as $4.22,2.50$ and 3.99 , respectively. In contribution analysis for DALY, the primary PM 2.5 accounted for $60 \%$ of the DALY of Jeonju and $71 \%$ of the DALY of Changwon. However, $\mathrm{NH}_{3}$ was the major contributor to the Iksan DALY, $49 \%$. Further contribution analysis on the local major emission sources and pollutants showed as follows: The Jeonju DALY was contributed by PM2.5 of "Dust" $21.1 \%, \mathrm{NH}_{3}$ of "Agriculture" $13.6 \%$ and PM2.5 of "Road vehicles" 13.5\%; The Iksan DALY was contributed by $\mathrm{NH}_{3}$ of "Agriculture", 47.6\%, PM2.5 of "Dust" $16.1 \%$ and PM2.5 of "Biomaterial incineration" 8.4\%; The Changwon DALY was contributed by PM2.5 of "Industrial combustion" $32.6 \%$, PM2.5 of "Non-road engines" $12.7 \%$ and PM2.5 of "Dust" $10.0 \%$.

Conclusions: The LCIA method can be utilized to identify the major emission sources and pollutants contributing to the local burden of disease and help the authority screening priorities. The distinct differences in the DALY of the same city between two methods may imply that the local burden of disease would be dominantly determined by flowing primary and secondary PM2.5 from the outside of the city boundary.

Key Words: Fine particulate matter, PM2.5, Disability adjusted life years, Human health burdens, Life cycle impact assessment, Air pollutant emission

\footnotetext{
${ }^{\dagger}$ Corresponding author E-mail: swjeong@kunsan.ac.kr Tel: 063-469-4767 Fax: 063-469-4964

${ }^{+1}$ Corresponding author E-mail: gts@changwon.ac.kr Tel: 055-213-3746 Fax: 055-281-3011

(C) 2019, Korean Society of Environmental Engineers
} 


\title{
연구논문
}

\section{전과정영향평가기법을 활용한 초미세먼지의 지역 건강영향 정량화와 배출원 기여도 연구}

\author{
정승우 ${ }^{1+} \cdot$ 서규태 $^{2,++}$ \\ '군산대학교 환경공학과 \\ 2창원대학교 토목환경화공융합공학부
}

목적 : 전주시, 익산시, 창원시 초미세먼지 흡입으로 인해 발생할 수 있는 건강영향을 건강영향 지수인 장애보정 손실년수(DALY)로 정량화하고, 지역 건강에 가장 영향을 미치는 대기오염 배출원 및 배출물질 기여도를 분석하 였다.

방법: PM2.5 흡입에 의한 DALY 정량화에 두 가지 방법을 사용하였다. 첫째, PM2.5 농도-건강반응 방법은 전주, 익산 및 창원 30세 이상 연령별 자료, 미세먼지농도-건강반응계수, 심각도계수 및 PM2.5 연평균 자료를 바탕으로 심폐질환 및 폐암에 대한 DALY를 산정하였다. 두 번째 전과정영향평가(LCIA)방법은 지역 대기오염물질 배출량, 호흡률 및 건강영향계수를 고려하여 1차 및 2차 PM2.5 물질이 야기하는 건강영향을 DALY로 산정하였다.

결과 및 토의: PM2.5 연평균 농도에 반응하는 건강영향 산정결과 인구수 1000 명당 DALY (DALY/1000명)는 익산 35.03 , 전주 25.44 , 창원 22.24 이었다. LCIA방법에 의한 PM2.5 흡입 건강영향은 DALY/1000명 단위로 전주 4.22, 익산 2.50 , 창원 3.99 로 예측되었다. 각 지역 DALY 기여도 분석에서 전주는 1 차 PM2.5 물질에 의한 기여도 $(60 \%)$ 가 가장 높게 나타났고, 익산은 $\mathrm{NH}_{3}$ 가 형성하는 2 차 $\mathrm{PM} 2.5$ 에 의한 건강영향 기여도 $(49 \%)$ 가 가장 높은 특 징이 있었다. 창원은 1 차 PM2.5 배출에 의한 건강영향 기여도 $(71 \%)$ 가 가장 높았다. 더 나아가 각 지역 DALY에 가장 영향을 미치는 대기오염 배출원 및 배출물질을 세부 분석한 결과, 전주는 “비산먼지의 PM2.5"가 총 DALY 의 $21.1 \%$ 를 차지하고, "농업의 $\mathrm{NH}_{3}$ " $13.6 \%$, "도로이동오염원의 $\mathrm{PM} 2.5$ " $13.5 \%$ 순이었다. 익산은 "농업의 $\mathrm{NH}_{3}$ "가 총 DALY의 47.6\%를 차지하고, "비산먼지의 PM2.5" $16.1 \%$, “생물성연소의 PM2.5" $8.4 \%$ 순이었다. 창원은 "제 조업연소의 PM2.5"가 전체 DALY의 $32.6 \%$, “비도로 이동오염원의 PM2.5" $12.7 \%$, “비산먼지의 PM2.5" $10.0 \%$ 순이었다.

결론 : LCIA에 의한 건강영향 정량화 방법은 지역 건강에 영향을 미칠 수 있는 대기오염물질 및 주요 배출원을 선 별할 수 있어 각 지역에 적합한 미세먼지 우선관리 대책수립에 도움을 줄 수 있다. PM2.5 농도에 반응하는 건강 영향 DALY결과와 지역 대기오염물질 배출량에 근거한 LCIA의 DALY결과가 큰 차이를 나타내는 것은 각 시공간 적 범위 내에서 발생되는 PM2.5 물질보다 밖에서 유입되는 1차 및 2차 PM2.5 물질에 의해 지역 건강이 더 영향 을 받을 수 있음을 시사한다.

주제어: 초미세먼지, PM2.5, 장애보정손실년수, 건강부담, 전과정영향평가, 대기오염물질 배출량

\section{1. 서 론}

미세먼지는 사람의 호흡기에 지대한 건강영향은 미치는 것 으로 알려져 있다. ${ }^{1)}$ 세계보건기구(World Health Organization : WHO)는 2012년 세계 보건 통계로부터 미세먼지(PM10 및 $\mathrm{PM} 2.5$ ) 노출에 의해 전 세계 300 만 명이 사망한 것으로 추정하 였다. WHO는 한국의 경우 평균 PM2.5 농도 $27 \mu \mathrm{g} / \mathrm{m}^{3}$ 의 노출 에 11,000 여명이 사망한 것으로 예측하였고, 인구 십만 명 당
사망자 수는 우리나라 23 명, 일본 24 명, 중국 76 명으로 예측하 였다. ${ }^{2)}$ 질병 및 사망자 통계로부터 미세먼지의 건강영향 연관 성과 이를 정량화하고자 하는 연구가 최근 활발하게 이루어지 고 있으나 미세먼지 배출원의 배출물질 발생, 호흡에 의한 노 출, 노출에 의한 건강영향 등 일련의 전과정에 걸친 연구는 많이 이루어지지 않았다. 또한 암모니아 $\left(\mathrm{NH}_{3}\right)$, 질소산화물 $\left(\mathrm{NO}_{\mathrm{x}}\right)$, 이산화황 $\left(\mathrm{SO}_{2}\right)$ 물질 등도 2차 PM2.5 에어로졸을 형성할 수 있지만 이에 대한 건강영향 정량화 연구도 많이 수행되지 
않았다. 본 연구는 전과정평가(Life Cycle Assessment: LCA) 방 식에 따라 대기오염 배출물질량과 인체건강영향 관계를 나타 내는 지역 특성화계수를 도출하고 건강영향에 지대한 영향을 미치는 지역 PM2.5 배출원을 식별하는 방안을 제시하였다. 대기오염물질로 인한 건강영향을 정량화하는 방법은 두 가지로 접근할 수 있다. 첫째, 사람이 대기오염물질 농도에 따라 질병을 유발하거나 사망에 이르는 정도를 장애보정손 실년수(Disability Adjusted Life Years: DALY)로 예측하는 방법이 있다. ${ }^{14)}$ 두 번째, 대기로 배출되는 배출량 정보로 부터 지역 내 거동을 고려하여 인체 흡입량을 산정하고 흡 입량에 반응하는 건강영향을 DALY로 정량화하는 방법이 있다. ${ }^{5 \sim 9)}$ 후자가 LCA의 건강영향평가방법이다. DALY는 조기사망에 따른 손실수명년수(Years of Life Lost: YLL)에 장애생활년수(Years Lived with Disability: YLD)를 합한 수 치로 $\mathrm{WHO}$ 에서 사용하고 있는 대표적 건강손실년수 지표 이다. ${ }^{2)}$ 본 연구는 상기 두 가지 방법으로 건강영향을 정량 화하고 토의하였다. 최근 Gronlund et al. ${ }^{9}$ 은 두 가지 건강 영향평가방법에 적용되는 주요 정량화 계수들을 제시하고 있어 본 연구에서 활용하였다.

전과정평가는 어떤 제품, 공정 및 활동의 발생으로부터 소멸까지의 전과정에 걸쳐 사용되고 배출되는 에너지 및 물질이 환경에 미치는 영향을 평가하는 환경영향평가방법 중 하나이다. 최근 미세먼지로 인한 환경영향이 매우 중요 하게 대두되면서 전과정평가에서도 초미세먼지 PM2.5 배 출로 인한 건강영향을 정량화하는 연구가 매우 활발하게 진행되고 있다. 전과정평가에서 인체 건강영향은 DALY로 산정된다. ${ }^{5 \sim 9)}$

최근 United Nations Environment Programme/Society of Environmental Toxicity and Chemistry, Life Cycle Initiative의 국제전문가 그룹에서 초미세먼지의 인체 건강영향 정량화 방 법론을 전과정영향평가(Life cycle impact assessment: LCIA) 기 본구조에 적용하여 설계한 방법론을 제시하고 있다. ${ }^{8)}$ 이들은 1차 PM2.5 미세먼지와 2차 PM2.5 에어로졸을 생성하는 $\mathrm{NH}_{3}$, $\mathrm{NO}_{\mathrm{x}}, \mathrm{SO}_{2}$ 물질간 상대적 미세먼지 생성 기여도를 나타내는 첫 번째 계수, “미세먼지 형성 특성화계수”를 도출하고 PM2.5가 야기하는 건강피해는 두 번째 계수 "미세먼지 DALY 특성화계수”를 도출하여 사용할 것을 권고하고 있다. ${ }^{8)}$ 현재 전과정평가에서 사용하는 미세먼지 DALY 특성화 계수 는 대부분 전 세계, 대륙 및 국가 단위 값들이 제시되어 있으며 지역 특이적 계수 값은 아직 많이 연구되지 않았다.

본 연구의 첫 번째 목적은 우리나라 3 개 시(市)의 지역
특이적 “초미세먼지 건강영향(DALY) 특성화계수”를 산정 하여 PM2.5로 인한 각 지역 건강영향을 정량화하고자 하 였고, 두 번째 목적은 각 지역 건강에 지대한 영향을 미치 는 대기오염물질 및 배출원의 식별할 수 있는 방안을 제시 하고자 하였다. (본 논문은 “전라북도 미세먼지 특성분석 및 관리대책 수립연구 보고서"10) 일부 내용을 전면 재구성 하였습니다.)

\section{PM2.5에 의한 건강영향 정량화 방법}

\subsection{PM2.5 농도에 반응하는 건강영향 정량화}

일정한 미세먼지 농도에 계속 노출되어 질병이 유발되는 정도를 질병부담(Burden of disease)이라 하며 DALY로 산 정된다.

\author{
Burden of disease \\ $=\mathrm{CRF} \times \mathrm{SF} \times[$ population $] \times[\mathrm{PM} 2.5$ concentration $]$
}

여기서, $\mathrm{CRF}$ 는 미세먼지농도-인체반응계수(concentration response factor, death $/ \mu \mathrm{g} / \mathrm{m}^{3}$ ), $\mathrm{SF}$ 는 심각도 계수(severity factor, $\mathrm{DALY} /$ death 또는 YLL/death)이다. 본 연구는 Gronlund et al. ${ }^{9)}$ 연구팀이 제안한 연령별 PM2.5의 CRF 및 SF 계수를 적용하였으며 본 연구대상 지역 연령별 인구수에 각 해당 하는 계수를 적용하였다. $\mathrm{CRF}$ 는 심폐질환(Cardiopulmonary disease) 및 폐암(Lung cancer)에 의한 질병정보가 유효한 30 세 이상 연령에 대해 제시되어 있다.

본 연구는 전주시, 익산시, 창원시를 대상 지역으로 선정 하였다. 익산시는 PM2.5 연평균 농도가 상대적으로 높게 분포하여 대표지역으로 선정하였고, 전주시는 익산시에 비 해 인구가 많고 농업지역보다 도시화된 지역이 상대적으로 높아 비교 도시로 선정하였다. 창원시는 앞의 두 도시에 비 해 인구가 많고 공업도시로서 대기오염배출물질이 상대적 으로 많아 비교도시로 선정하였다.

본 연구는 전주시, 익산시 및 창원시를 대상으로 인구수 및 연간 미세먼지 평균농도를 사용하였다(Table 1참조). 기 준년도는 2015년으로 설정하였다. 그 이유는 최근 유효한 대기오염물질 배출량 자료가 2015년이므로 일관된 년도를 사용하고자 하였다. 단, 전주시의 2015년 PM2.5 연평균 농 도가 유효하지 않아 2016년 자료를 사용하였다. 전주시, 익 산시 및 창원시 30 세 이상 연령별 자료, $\mathrm{CRF}, \mathrm{SF}$ 및 각 지 역 미세먼지농도 자료를 바탕으로 식 (1)에 의해 심폐질환 및 폐암에 대한 DALY와 YLL을 각각 산정하였다.

Table 1. Population and average PM2.5 concentration of three Korean cities in 2015.

\begin{tabular}{|c|c|c|c|}
\hline Area & $\begin{array}{c}\text { Population } \\
(\text { Year 2015) }\end{array}$ & $\begin{array}{c}\text { Population } \\
\text { over age } 30^{14)}\end{array}$ & $\begin{array}{c}\text { Average PM2.5 } \\
\left(\mu \mathrm{g} / \mathrm{m}^{3} \text {, Year } 2015\right)^{17)}\end{array}$ \\
\hline Jeonju & 651,539 & 412,832 & 31 (Year 2016), not available in 2015 \\
\hline Iksan & 296,968 & 190,049 & 40 \\
\hline Changwon & $1,039,710$ & 681,303 & 26 \\
\hline
\end{tabular}


Table 2. Numerical parameter values for calculation of intake fraction.

\begin{tabular}{|c|c|c|c|c|c|c|}
\hline Symbol & Definition & Unit & Jeonju & Iksan & Changwon & References \\
\hline BR & Breathing rate & $\mathrm{m}^{3} /$ day & & 15.7 & & $M O E^{13)}$ \\
\hline \multirow{2}{*}{$f_{t, i}$} & \multirow{2}{*}{$\begin{array}{l}\text { Fraction of time per day } \\
\text { spent indoors }\end{array}$} & - & & 0.890 & & \multirow{2}{*}{$\mathrm{MOE}^{13)}$} \\
\hline & & $\min$ & & 1,281 & & \\
\hline POP & Human population count & capita & 651,539 & 296,968 & $1,039,710$ & Year 2015, KOSIS ${ }^{14)}$ \\
\hline V & Air volume & $m^{3}$ & $3.025 E+11$ & $7.456 \mathrm{E}+11$ & $1.101 \mathrm{E}+12$ & Calculated \\
\hline A & Air cross section area & $m^{2}$ & $2.06 . E+08$ & $5.07 . E+08$ & 7.48.E+08 & Calculated \\
\hline $\mathrm{h}$ & Atmospheric mixing height & $\mathrm{m}$ & \multicolumn{3}{|c|}{1,472 (four season average) } & $\operatorname{Jin}^{15)}$ \\
\hline LPD & linear population density & capita/m & 45.45 & 13.19 & 38.02 & Calculated \\
\hline Area & City area & $\mathrm{km}^{2}$ & 205.531 & 506.544 & 747.671 & Year 2015, KOSIS ${ }^{14)}$ \\
\hline$X F$ & $\begin{array}{l}\text { Human inhalation exposure } \\
\text { factor }\end{array}$ & /day & 3.73.E-06 & 6.90.E-07 & 1.64.E-06 & Calculated \\
\hline$K_{\text {dep }}$ & $\begin{array}{c}\text { Removal rate coefficient via } \\
\text { bulk deposition }\end{array}$ & /day & \multicolumn{3}{|c|}{0.059} & Calculated \\
\hline$V_{\text {dep }}$ & $\begin{array}{l}\text { Atmospheric particle } \\
\text { deposition velocity }\end{array}$ & $\mathrm{m} / \mathrm{d}$ & \multicolumn{3}{|c|}{86.4 (Global average) } & Seinfeld and Pandis ${ }^{16)}$ \\
\hline $\mathrm{FF}$ & Fate factor & day & 17.04 & 17.04 & 17.04 & Calculated \\
\hline \multirow[t]{2}{*}{$\mathrm{iF}$} & \multirow[t]{2}{*}{ Intake fraction } & $\begin{array}{l}\text { kg }_{\text {inhaled }} / \\
\text { kgemitted }\end{array}$ & 6.36.E-05 & 1.18.E-05 & 2.79.E-05 & \multirow[t]{2}{*}{ Calculated } \\
\hline & & $\mathrm{ppm}$ & 63.60 & 11.76 & 27.90 & \\
\hline
\end{tabular}

\subsection{PM2.5 및 2차 PM2.5 형성가능 물질 배출량 자료를 활용한 건강영향 정량화(LCIA방법)}

LCIA는 전과정목록분석(Life cycle inventory: LCI)단계에 서 산정된 물질의 배출량에 환경영향 특성화계수를 곱해 각 분야 환경영향을 정량화한다. 세 개 시의 PM2.5 및 2차 $\mathrm{PM} 2.5$ 를 형성하는 $\mathrm{SO}_{\mathrm{x}}, \mathrm{NO}_{\mathrm{x}}, \mathrm{NH}_{3}$ 의 배출량에 건강영향 특 성화계수를 곱해 각 지역의 DALY를 산정한다. 이 건강영향 특성화 계수에는 배출물질 발생, 호흡에 의한 노출, 노출에 의한 건강영향 등 일련의 전과정을 포함한 단위 계수이다.

“초미세먼지 건강영향 특성화계수”(Characterization factors for primary PM2.5 and secondary PM2.5, CF, DALY/ $/ \mathrm{kg}_{\mathrm{emitted}}$ ) 는 연간 배출된 오염물질량 $\left(\mathrm{kg}_{\mathrm{emitted}}\right)$ 이 사람 건강에 미치는 질병 정도를 DALY로 정량화하기 위한 계수이다. 특성화 계 수는 아래 식으로부터 도출된다. ${ }^{8,9,11)}$

$C F=[S F \times D R F] \times[X F \times F F]=E F \times i F$

여기서, SF (Severity factor, DALY/death)는 심각도 계수 로써 미세먼지 흡입으로 인해 발생하는 심폐질환 또는 폐 암으로 의한 사망(death)을 DALY로 나타낸다. DRF (Doseresponse factor, cases $/ \mathrm{kg}_{\text {inhaled})}$ 는 흡입-반응계수로써 연간 흡 입 $\left(\mathrm{kg}_{\text {inhaled }}\right)$ 에 의한 치사 또는 사망 건 수(cases)를 나타낸다. $\mathrm{XF}$ (Exposure factor, $\mathrm{kg}_{\text {inhaled }} / \mathrm{kg}_{\text {air }}$ )는 노출계수이며, 대기 오염 물질 $\left(\mathrm{kg}_{\text {air }}\right)$ 중 연간 흡입 $\left(\mathrm{kg}_{\text {inhaled }}\right)$ 되는 비율을 나타낸다. $\mathrm{FF}$

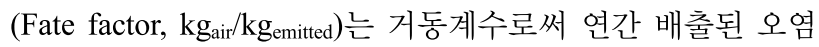
물질량 $\left(\mathrm{kg}_{\text {emitted, year }}\right)$ 중 오염매체(대기)에 존재하는 오염물질 양 $\left(\mathrm{kg}_{\mathrm{air}}\right)$ 을 나타낸다.
상기 “초미세먼지 건강영향 특성화계수” 식은 영향계수 $\mathrm{EF}$ (Effect factor, DALY $/ \mathrm{kg}_{\text {inhaled}}$ )와 흡입률 $\mathrm{iF}$ (Intake fraction, $\mathrm{kg}_{\text {inhaled }} / \mathrm{kg}_{\text {emitted }}$ 로 간단히 정리하여 사용하고 있다. $\mathrm{EF}$ 는 심 각도 계수(SF)와 흡입-반응 계수(DRF)의 곱으로 산정하며, $\mathrm{iF}$ 는 노출계수 $(\mathrm{XF})$ 와 경로계수 $(\mathrm{FF})$ 의 곱이다. 최종적으로 두 계수의 곱은 “초미세먼지 건강영향 특성화계수”를 나타낸다. 본 연구에서는 전주, 익산, 창원에 대해 $\mathrm{PM} 2.5, \mathrm{SO}_{\mathrm{x}}, \mathrm{NO}_{\mathrm{x}}$, $\mathrm{NH}_{3}$ 의 “지역 특이적 초미세먼지 건강영향 특성화 계수”를 각각 산정하였다.

\section{3. if, 흡입률 산정}

본 연구에서 상기 언급한 $\mathrm{iF}$ 산정은 최근 Fantke et al. ${ }^{12)}$ 가 제안한 새로운 식을 적용하였다. 제안된 수식은 발생원 으로부터 발생된 미세먼지가 사람에 흡입되기까지 거동과 노출과정을 모두 포함하고 있어 더욱 발전된 형태이다. 여 기서도 흡입률 $\mathrm{iF}=\mathrm{XF}$ (노출계수) $\times \mathrm{FF}$ (거동계수)로 산정

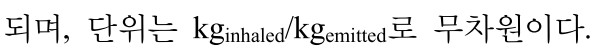

흡입을 통한 노출계수(Human inhalation exposure factor, $\mathrm{XF}$ )는 다음과 같이 정의된다. ${ }^{12)}$

$$
X F=\frac{B R \times\left(1-f_{t, i}\right) \times P O P}{V}
$$

$\mathrm{XF}=$ Human inhalation exposure factor, /day

$\mathrm{BR}=$ Breathing rate, $\mathrm{m}^{3} /$ day

$\mathrm{f}_{\mathrm{t}, \mathrm{i}}=$ Fraction of time per day spent indoors POP = Human population count, capita

$\mathrm{V}=$ Air volume, $\mathrm{m}^{3}$ 
공기부피(V)는 공기 단면적과 대기 혼합고도의 곱으로 정 의되고, 공기 단면적은 다시 인구수(POP)/인구밀도비례치 (LPD)의 제곱으로 산정된다. $\mathrm{LPD}$ 는 인구수를 도시면적의 제곱근으로 나눠준 값으로서 도시 폭 당 인구수를 보여주 는 지표이다. ${ }^{11,12)}$

$$
\begin{aligned}
& V=A \times h \\
& A=\left(\frac{P O P}{L P D}\right)^{2} \\
& \mathrm{~A}=\text { Air cross section area, } \mathrm{m}^{2} \\
& \mathrm{~h}=\text { Atmospheric mixing height, } \mathrm{m} \\
& \mathrm{LPD}=\text { Linear population density, capita/m }
\end{aligned}
$$

$\mathrm{FF}$, 거동계수는 배출된 오염물질이 환경매체(대기)에 체류 하는 정도를 나타내며 오염물질이 대기에서 제거되는 속도 의 역수개념으로 대기 중 오염물질이 존재하는 시간(day)을 나타낸다. 따라서 본 연구에서는 지역 내 미세먼지는 침강하 여 제거되는 경우와 사람이 호흡하는 경우로만 가정하여 거 동계수를 산정하였다. 침강속도(Removal rate coefficient via bulk deposition)는 대기입자 침강속도(Atmospheric particle deposition velocity)를 대기혼합고(Atmospheric mixing height) 로 나누었다. ${ }^{12)}$ 침강속도는 세계 도시 평균 값(Global average atmospheric particle deposition velocity in urban areas) ${ }^{16}$ )을 사용하였고 대기혼합고는 전주시의 사계절 평균 문헌 값 ${ }^{15)}$ 을 사용하였다(Table 2 참조).

\subsection{EF, 영향계수}

PM2.5 흡입에 따른 건강영향 계수는 Gronlund et al. ${ }^{9}$ 가 심폐질환과 폐암, 각각에 대해 제시하고 있는 $\mathrm{DALY} / \mathrm{kg}$ $\mathrm{PM} 2.5$ (흡입), YLL/kg PM2.5 (흡입) 값들을 바로 활용하였 다(Table 3 참조).

\section{5. 대기오염물질 배출량}

최근 2015년 국가 대기오염물질 배출량 자료 ${ }^{18)}$ 를 활용하 였다. 전주, 익산, 창원의 $\mathrm{PM} 2.5, \mathrm{SO}_{\mathrm{x}}, \mathrm{NO}_{\mathrm{x}}, \mathrm{NH}_{3}$ 각 배출량 자료는 Table 4와 같다.

\section{3. 결과 및 고찰}

\subsection{PM2.5 농도에 반응하는 건강영향 정량화 결과}

전주시, 익산시 및 창원시 30 세 이상 연령별 자료, $\mathrm{CRF}$, $\mathrm{SF}$ 및 각 지역 미세먼지농도 자료를 바탕으로 심폐질환 및

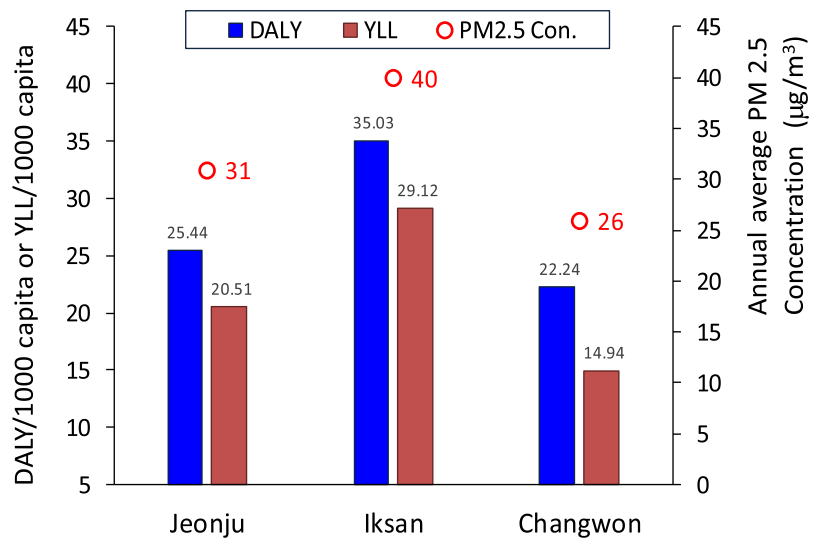

Fig. 1. The annual burden of disease estimates based on ambient levels of PM2.5 (Year 2015): estimated as the Disability adjusted life years (DALY) and Years of Life Lost (YLL) per 1000 capita.

폐암에 대한 DALY과 YLL를 각각 정량화하였다. PM2.5에 의한 총 $\mathrm{DALY}$ 는 전주시 10,504 , 익산시 6,657 , 창원시 15,154 로 산정되었다. 이 수치는 도시 전체의 DALY이다. 식 (1)에 나타낸 바와 같이 질병부담은 PM2.5의 농도가 높 거나 노출 인구가 많으면 높게 나올 수 있다. 익산시의 2015년 PM2.5 연평균 농도가 $40 \mu \mathrm{g} / \mathrm{m}^{3}$ 로 전주시 $31 \mu \mathrm{g} / \mathrm{m}^{3}$ (2016년)보다 높지만 노출 인구가 적어 전체 DALY는 전주 보다 적게 산정되었다. 그러나 인구수 1000 명당 DALY를 재산정한 결과, 익산이 $35.03 \mathrm{DALY} / 1000$ 명로서 전주 25.44 $\mathrm{DALY} / 1000$ 명보다 높다(Fig. 1 참조). 따라서 이 방법에서 는 노출 인구수 보다 PM2.5 농도가 절대적으로 결과에 영 향을 미치고 있다.

미세먼지에 의한 YLL은 전주시 8,467, 익산시 5,533, 창 원시 10,184 로 산정되었다. 인구수 1000 명당 $\mathrm{YLL}$ 를 재산 정한 결과는 익산이 $29.12 \mathrm{YLL} / 1000$ 명로서 전주 20.51 $\mathrm{YLL} / 1000$ 명보다 높다. 창원은 2015년 PM2.5 연평균 농도 가 상대적으로 적은 $26 \mu \mathrm{g} / \mathrm{m}^{3}$ 로 DALY (22.24 DALY/1000 명)와 YLL (14.94 YLL/1000명)이 보다 적게 예측되었다. 익산시 $35.03 \mathrm{DALY} / 1000$ 명의 의미는 PM2.5 농도 $40 \mu \mathrm{g} / \mathrm{m}^{3}$ 에 지속적으로 노출될 경우 인구 1000 명 기준으로 조기사 망년 수가 29.12년이고 나머지 년수인 5.91년은 질병을 가지고 살아가는 년수이다. WHO는 2012년 세계건강통계 로부터 우리나라가 PM2.5 농도 $27 \mu \mathrm{g} / \mathrm{m}^{3}$ 에 노출되어 $253,512 \mathrm{DALY}$ 가 발생하는 것으로 예측하였는데 이 값은 $5.11 \mathrm{DALY} / 1000$ 명에 해당한다. $\mathrm{WHO}$ 는 우리나라 전반에 걸친 대푯값들을 활용하여 예측하여 본 연구의 지역 예측

Table 3. PM2.5 Effect factor (EF) due to inhalation of fine particulates (Gronlund et al. ${ }^{9}$ ).

\begin{tabular}{cccc} 
Effect factor & Cardiopulmonary & \multicolumn{2}{c}{ Lung cancer } \\
DALY/kg PM2.5 (inhalation) & 65 & 9.7 \\
\hline YLL/kg PM2.5 (inhalation) & 50 & 9.6 \\
\hline
\end{tabular}




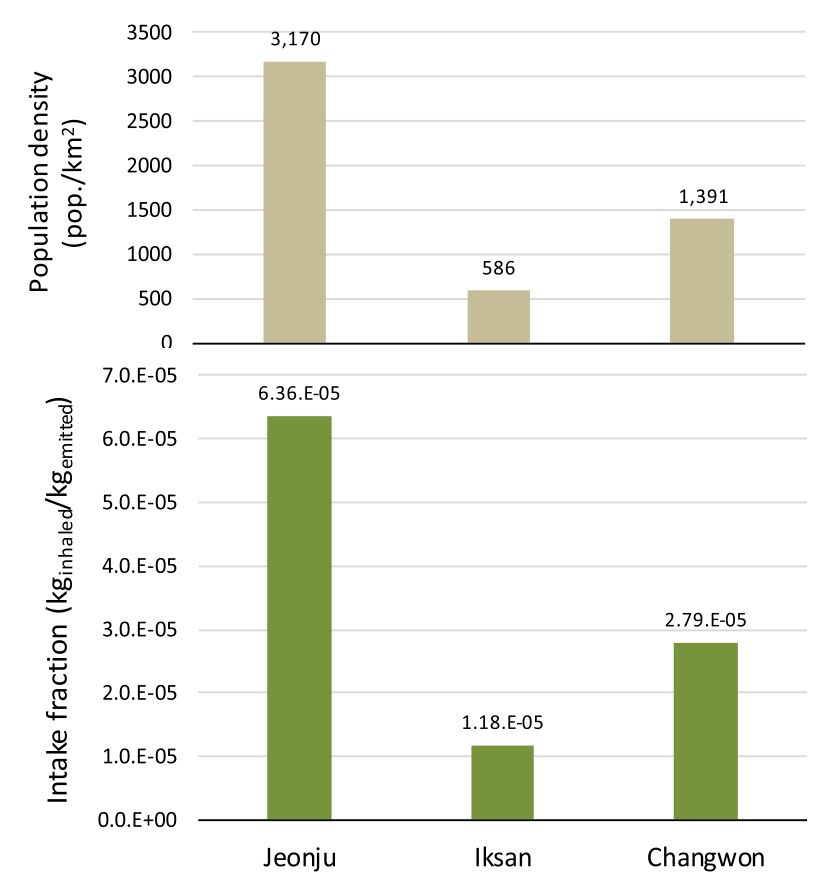

Fig. 2. Intake fractions and population densities for three Korean cities.

값보다 극히 적은 값이 산출된 것으로 보여진다.

\section{2. iF 흡입률 산정 결과}

산정된 $\mathrm{iF}$, 흡입률 $\left(\mathrm{kg}_{\text {inhaled }} / \mathrm{kg}_{\text {emitted}}\right)$ 은 전주 6.36.E-05 (63.6 $\mathrm{ppm})$, 익산 1.18.E-05 (11.8 ppm), 창원 2.79.E-05 (27.9 ppm) 로 산정되었다(Fig. 2 참조). 흡입률은 PM2.5 배출량 및 농 도와 무관하게 지역 대기환경 및 노출인자에 의해서만 계 산된다. 전주의 대기오염물질 흡입률은 익산의 5.4 배에 달 한다. 흡입률에 영향을 미치는 주요인자는 인구밀도인데, 전주가 3,170 명 $/ \mathrm{km}^{2}$ 로서 익산 586 명 $/ \mathrm{km}^{2}$, 창원 1,390 명 $/ \mathrm{km}^{2}$ 보다 상대적으로 높아 배출된 대기오염물질의 흡입률이 높
게 산정되었다.

\subsection{CF, PM2.5 배출-흡입에 따른 "초미세먼지 건강영향 특성화계수"}

PM2.5 배출-흡입에 따른 “초미세먼지 건강영향 특성화계 수”는 심폐질환과 간암 각각에 대해 산정된 계수 값을 더 해 얻어졌다. PM2.5 특성화계수(DALY $/ \mathrm{kg}_{\mathrm{PM} 2.5, \mathrm{emitted}}$ )는 전주 시 4.75E-3, 익산시 8.79E-4, 창원시 2.08E-3으로 산정되었 다. 우리나라 세 개 시의 PM2.5 건강영향 특성화 계수는 Gronlund et al. ${ }^{9}$ 가 제시한 세계 평균 PM2.5 건강영향 특성 화 계수 $1.2 \mathrm{E}-03 \mathrm{DALY} / \mathrm{kg}_{\mathrm{PM} 2.5, \mathrm{emitted}}$ 보다 높은 값을 보였 다. 건강영향 특성화 계수 값이 큰 지역은 동일한 PM2.5가 배출되더라도 특성화 계수 값이 작은 지역보다 DALY 값 이 크게 산정되는 것을 의미한다.

$\mathrm{PM} 2.5$ 는 $\mathrm{SO}_{2}, \mathrm{NO}_{\mathrm{x}}, \mathrm{NH}_{3}$ 등이 2차 화학반응을 통해 또한 형성될 수 있으므로 각 물질에 대한 2차 PM2.5 형성 특성 화계수를 산정하였다. Gronlund et al. ${ }^{9}$ 가 제시하고 있는 각 물질의 특성화계수 비를 적용하여 $\mathrm{SO}_{\mathrm{x}}$ 배출-PM2.5형성-흡 입에 따른 건강영향 특성화 계수, $\mathrm{NO}_{\mathrm{x}}-\mathrm{PM} 2.5$ 형성-흡입에 따른 건강영향계수, $\mathrm{NH}_{3}$ 배출-PM2.5형성-흡입에 따른 건강 영향계수를 Table 4에 제시하였다. PM2.5: $\mathrm{SO}_{2}: \mathrm{NO}_{\mathrm{x}}$ : $\mathrm{NH}_{3}$ 간 특성화계수 비는 $1: 0.058: 0.012: 0.108$ 이다. 2차 $\mathrm{PM} 2.5$ 형성물질 중 $\mathrm{NH}_{3}$ 가 PM2.5를 형성하는 비율이 가장 높다. $\mathrm{NH}_{3}$ 배출량의 $10.8 \%$ 는 PM2.5를 형성하는 것으로 간 주된다.

전주, 익산, 창원의 각 1 차 PM2.5 배출-흡입-건강영향특 성화 계수와 2차 PM2.5 형성물질-흡입-건강영향 특성화계 수는 Table 4에 정리하였다.

\subsection{PM2.5 및 2차 PM2.5 형성가능 물질 배출량 자료를 활용한 건강영향 정량화(LCIA방법) 결과}

$\mathrm{PM} 2.5$ 및 2차 $\mathrm{PM} 2.5$ 형성 $\mathrm{SO}_{\mathrm{x}}, \mathrm{NO}_{\mathrm{x}}, \mathrm{NH}_{3}$ 각 “지역 특이

Table 4. Characterization factors for the primary PM2.5 and secondary PM2.5 impacts per kg emitted, in terms of DALY and the annual air pollutant emission data for three Korean cities.

\begin{tabular}{|c|c|c|c|}
\hline Air pollutants & Jeonju & Iksan & Changwon \\
\hline \multicolumn{4}{|l|}{ PM2.5 } \\
\hline CF (DALY/kg $\left.{ }_{\text {PM2.5,emitted }}\right)$ & $4.75 \mathrm{E}-3$ & 8.79E-4 & $2.08 \mathrm{E}-3$ \\
\hline Emission $(\mathrm{kg} / \mathrm{yr})^{18)}$ & 346,608 & 340,201 & $1,411,515$ \\
\hline \multicolumn{4}{|l|}{$\mathrm{SO}_{x}$} \\
\hline CF (DALY/kgsox,emitted) & $2.73 \mathrm{E}-4$ & $5.05 \mathrm{E}-5$ & $1.20 \mathrm{E}-4$ \\
\hline Emission $(\mathrm{kg} / \mathrm{yr})^{18)}$ & 606,343 & 687,940 & $3,782,252$ \\
\hline \multicolumn{4}{|l|}{$\mathrm{NO}_{x}$} \\
\hline CF (DALY/kg NOx,emitted $)$ & $5.54 \mathrm{E}-5$ & $1.03 E-5$ & $2.43 E-5$ \\
\hline Emission $(\mathrm{kg} / \mathrm{yr})^{18)}$ & $6,585,197$ & $3,967,180$ & $15,224,331$ \\
\hline \multicolumn{4}{|l|}{$\mathrm{NH}_{3}$} \\
\hline CF (DALY/kg NH3,emitted $)$ & $5.15 \mathrm{E}-4$ & $9.52 \mathrm{E}-5$ & $2.26 \mathrm{E}-4$ \\
\hline Emission $(\mathrm{kg} / \mathrm{yr})^{18)}$ & $1,112,225$ & $3,851,628$ & $1,708,480$ \\
\hline
\end{tabular}


Table 5. Estimated regional burden of disease (DALY) using annual average PM2.5 concentration, concentration-response factor and severity factor ${ }^{\star * *}$.

\begin{tabular}{|c|c|c|c|c|c|c|c|c|c|}
\hline \multirow{2}{*}{ Ages } & \multicolumn{3}{|c|}{ Jeonju } & \multicolumn{3}{|c|}{ Iksan } & \multicolumn{3}{|c|}{ Changwon } \\
\hline & CPD $^{*}$ & $L C^{* *}$ & Total & CPD & LC & Total & CPD & LC & Total \\
\hline $30 \sim 34$ & 99.7 & 2.8 & 102.6 & 51.9 & 1.1 & 53.1 & 179.5 & 5.1 & 184.6 \\
\hline $35 \sim 39$ & 174.3 & 9.3 & 183.6 & 92.4 & 3.8 & 96.2 & 295.5 & 15.7 & 311.2 \\
\hline $40 \sim 44$ & 319.1 & 32.9 & 352.0 & 169.6 & 13.5 & 183.1 & 503.0 & 51.8 & 554.8 \\
\hline $45 \sim 49$ & 518.6 & 76.8 & 595.4 & 289.4 & 33.2 & 322.6 & 879.0 & 130.2 & 1009.3 \\
\hline $50 \sim 54$ & 760.9 & 136.0 & 896.9 & 456.4 & 63.2 & 519.6 & 1374.5 & 245.7 & 1620.2 \\
\hline $55 \sim 59$ & 1040.4 & 182.1 & 1222.4 & 667.2 & 90.5 & 757.7 & 1916.2 & 335.3 & 2251.6 \\
\hline $60 \sim 64$ & 375.8 & 511.5 & 887.3 & 246.7 & 260.2 & 506.9 & 662.4 & 901.5 & 1563.9 \\
\hline $65 \sim 69$ & 409.5 & 460.1 & 869.6 & 271.0 & 235.9 & 506.9 & 593.3 & 666.5 & 1259.8 \\
\hline $70 \sim 74$ & 1847.9 & -49.2 & 1798.7 & 1365.3 & -28.1 & 1337.2 & 2623.7 & -69.8 & 2554.0 \\
\hline $75 \sim 79$ & 1685.5 & -29.9 & 1655.6 & 1340.3 & -18.4 & 1321.9 & 2310.9 & -41.0 & 2270.0 \\
\hline $80<$ & 1951.7 & -11.8 & 1940.0 & 1057.3 & -5.0 & 1052.4 & 1584.3 & -9.6 & 1574.7 \\
\hline SUM & 9183.4 & 1320.6 & 10504.0 & 6007.5 & 650.0 & 6657.6 & 12922.4 & 2231.6 & 15154.0 \\
\hline
\end{tabular}

*CPD=Cardiopulmonary disease

$\star *$ LC=Lung cancer

$\star * \star$ Concentration-response factor (motality rate per $\mu \mathrm{g} / \mathrm{m}^{3} \mathrm{PM} 2,5$ ) and severity factor (DALY/death) of Gronlund et al. ${ }^{9)}$ were used

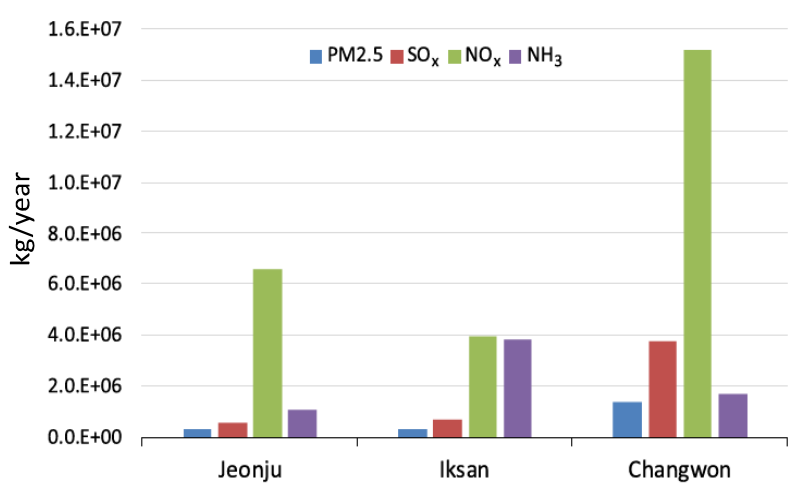

Fig. 3. Air pollutants emission of Year 2015. ${ }^{18)}$

적 초미세먼지 건강영향 특성화계수(CF)"와 각 물질의 지 역 배출량을 각각 곱하여 PM2.5 흡입에 따른 건강영향 DALY를 예측하였다(Table 5참조). Fig. 3은 3개 도시 2015 년 대기오염물질 배출량을 비교하였다. 창원시는 대표적 공업지역으로 $\mathrm{PM} 2.5, \mathrm{SO}_{\mathrm{x}}, \mathrm{NO}_{\mathrm{x}}$ 배출량은 두 도시에 비해 월등히 높았다. 그러나 $\mathrm{NH}_{3}$ 의 배출량은 익산시가 가장 높 아 농업지역 특징을 나타내고 있다.

대기오염물질 배출량 기준 PM2.5 흡입에 의한 총 DALY 는 전주시 2,750 , 익산시 741 , 창원시 4,151로 산정되었다. 창원시의 대기오염물질 배출량이 두 도시에 비해 상대적으 로 많아 총 DALY가 높게 산정되었다. 그러나, 인구수 1000 명당 총 DALY를 재산정한 결과는 Fig.4와 같이, 전주 $4.22 \mathrm{DALY} / 1000$ 명, 익산 $2.50 \mathrm{DALY} / 1000$ 명, 창원 3.99 $\mathrm{DALY} / 1000$ 명으로 전주시가 가장 높게 나타났고, 익산시가 가장 낮았다. 이는 앞서 Fig. 2에서 언급한 바와 같이 전주 시는 배출된 대기오염물질에 대한 흡입률이 $63.6 \mathrm{ppm}$ 으로

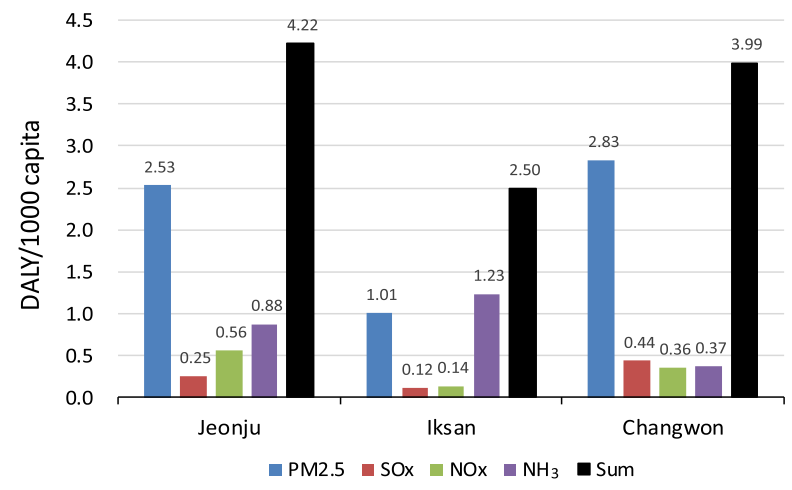

Fig. 4. The annual burden of disease estimates based on emissions of primary and secondary PM2.5 emissions (Year 2015) and the local DALY characterization factor.

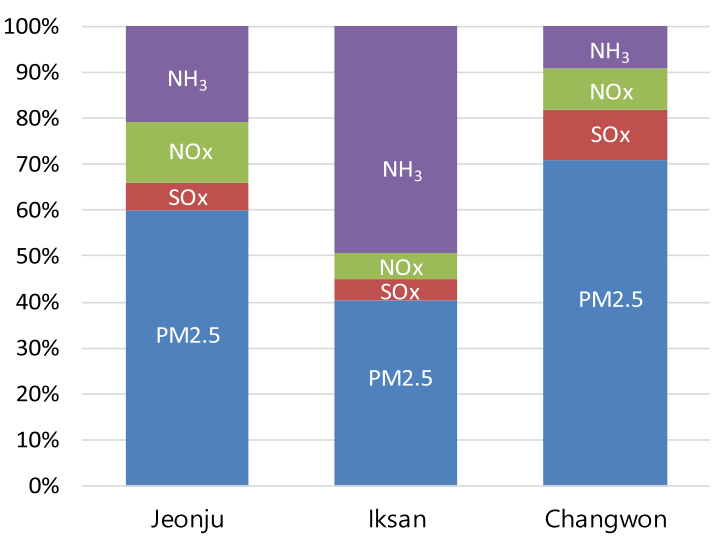

Fig. 5. Relative contribution of primary and secondary fine particulates to the local DALY: estimated from the air pollutants emission data of Year 2015 and the local DALY characterization factor. 


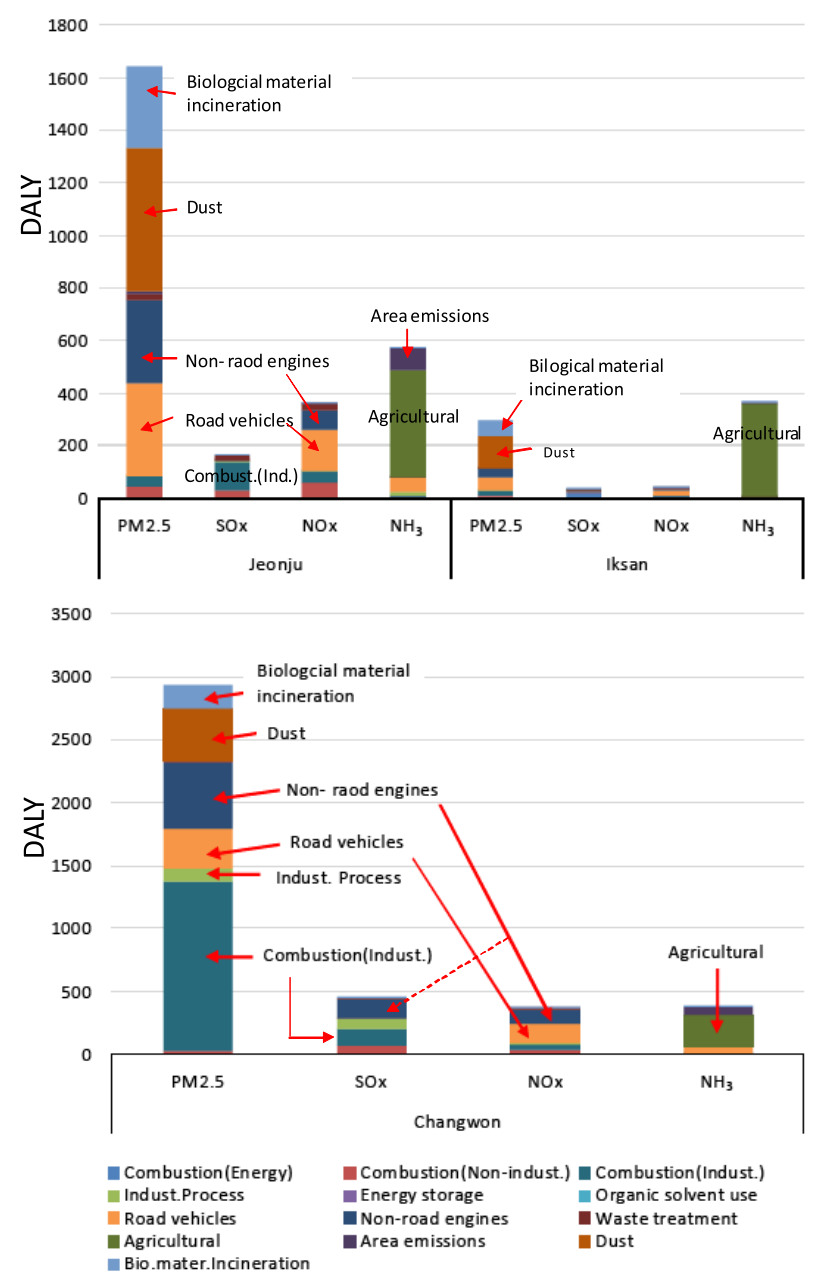

Fig.6. Contribution of air pollutants emission sources to the local DALY due to intake of primary and secondary fine particulates: estimated from the air pollutants emission data of Year 2015.

서 창원의 2.3배(27.9 ppm), 익산의 5.4배(11.8 ppm)에 달하 기 때문이다. 동일한 양의 대기오염물질 배출에 대해 인구 밀도가 높은 전주시가 상대적으로 흡입, 노출되어 건강영 향을 받는 인구수가 많다는 의미이다.

Fig. 5는 1차 및 2차 PM2.5 물질이 각 도시 건강영향, $\mathrm{DALY}$ 에 이바지하는 기여도를 나타내었다. 전주시는 1 차 $\mathrm{PM} 2.5$ 직접 배출이 전주시 전체 DALY의 $60 \%$ 를 차지한다. (2.53/4.22=60\%). 익산시는 $\mathrm{NH}_{3}$ 배출로 인해 형성되는 2차 PM2.5에 의한 건강영향 DALY기여도가 거의 과반수 $(1.23 / 2.5=49 \%)$ 를 차지하는 특징을 보였다. 창원시는 1 차 PM2.5 직접 배출에 의한 건강영향 $\mathrm{DALY}$ 기여도 $(2.83 / 3.99=71 \%)$ 가 매우 높게 나타났다.

각 지역에서 PM2.5 흡입에 의한 건강영향 DALY를 감소 시키기 위해 전주시와 창원시는 1차 PM2.5 직접 배출을 줄일 수 있는 대책이 필요하며, 익산시는 $\mathrm{NH}_{3}$ 직접 배출을 줄일 수 있는 대책마련이 우선 필요함을 시사한다.
Table 6. Contribution of emission source \& pollutant on the DALY of Jeonju due to intake of primary and secondary fine particulates.

\begin{tabular}{|c|c|c|c|}
\hline Emission source & Pollutant & DALY & Ratio \\
\hline Dust & PM2.5 & 549.85 & 0.200 \\
\hline Agricultural & $\mathrm{NH}_{3}$ & 406.12 & 0.148 \\
\hline Road vehicles & PM2.5 & 352.06 & 0.128 \\
\hline Non-road engines & PM2.5 & 313.07 & 0.114 \\
\hline Bio.mater.Incineration & PM2.5 & 309.16 & 0.112 \\
\hline Road vehicles & $\mathrm{NO}_{\mathrm{x}}$ & 154.36 & 0.056 \\
\hline Combustion (Indust.) & $\mathrm{SO}_{\mathrm{x}}$ & 111.02 & 0.040 \\
\hline Area emissions & $\mathrm{NH}_{3}$ & 83.93 & 0.031 \\
\hline Non-road engines & $\mathrm{NO}_{x}$ & 74.21 & 0.027 \\
\hline Combustion (Non-indust.) & $\mathrm{NO}_{\mathrm{x}}$ & 63.15 & 0.023 \\
\hline Road vehicles & $\mathrm{NH}_{3}$ & 56.08 & 0.020 \\
\hline Combustion (Non-indust.) & PM2.5 & 44.78 & 0.016 \\
\hline Combustion (Indust.) & $\mathrm{NO}_{x}$ & 43.53 & 0.016 \\
\hline Combustion (Indust.) & PM2.5 & 41.62 & 0.015 \\
\hline Combustion (Non-indust.) & $\mathrm{SO}_{x}$ & 30.67 & 0.011 \\
\hline Waste treatment & PM2.5 & 26.39 & 0.010 \\
\hline Waste treatment & $\mathrm{NO}_{x}$ & 26.37 & 0.010 \\
\hline Waste treatment & $\mathrm{SO}_{x}$ & 20.63 & 0.008 \\
\hline Indust.Process & $\mathrm{NH}_{3}$ & 12.95 & 0.005 \\
\hline Combustion (Non-indust.) & $\mathrm{NH}_{3}$ & 9.61 & 0.003 \\
\hline Area emissions & PM2.5 & 8.74 & 0.003 \\
\hline Combustion (Indust.) & $\mathrm{NH}_{3}$ & 3.20 & 0.001 \\
\hline Bio.mater.Incineration & $\mathrm{NO}_{x}$ & 2.63 & 0.001 \\
\hline Indust.Process & $\mathrm{SO}_{x}$ & 2.21 & 0.001 \\
\hline Indust.Process & PM2.5 & 1.03 & 0.000 \\
\hline Indust.Process & $\mathrm{NO}_{x}$ & 0.69 & 0.000 \\
\hline Road vehicles & $\mathrm{SO}_{x}$ & 0.50 & 0.000 \\
\hline Non-road engines & $\mathrm{SO}_{x}$ & 0.49 & 0.000 \\
\hline Non-road engines & $\mathrm{NH}_{3}$ & 0.31 & 0.000 \\
\hline Waste treatment & $\mathrm{NH}_{3}$ & 0.20 & 0.000 \\
\hline Bio.mater.Incineration & $\mathrm{SO}_{x}$ & 0.12 & 0.000 \\
\hline Area emissions & $\mathrm{NO}_{x}$ & 0.06 & 0.000 \\
\hline Bio.mater.Incineration & $\mathrm{NH}_{3}$ & 0.05 & 0.000 \\
\hline Total & & 2749.78 & 1.000 \\
\hline
\end{tabular}

\section{5. 대기오염물질 배출원의 건강영향 기여도 산정 결과}

대기오염물질 배출원별 세부 배출량 자료를 활용하여 각 배출원의 PM2.5 건강영향 DALY 기여도를 평가해 보았다. 앞 절에서 1차 PM2.5 및 2차 형성물질이 총 DALY에 끼치 는 기여도를 보았으며 본 절에서는 더 나아가 DALY 기여 도가 높은 세부 배출원 및 배출물질을 동시에 찾아보고자 하였다. Fig. 6은 각 지역 DALY에 가장 영향을 미치는 주 요 대기오염물질 배출원을 도시하였고 Table 6, 7, 8은 각 지역 배출원의 건강영향 기여도 산정결과를 정리하였다. 2015년 1차 PM2.5 및 2차 PM2.5 형성가능물질의 배출량 과 “지역 특이적 초미세먼지 건강영향 특성화계수”를 이용 
Table 7. Contribution of emission source \& pollutant on the DALY of Iksan due to intake of primary and secondary fine particulates.

\begin{tabular}{|c|c|c|c|}
\hline Emission source & Pollutant & DALY & Ratio \\
\hline Agricultural & $\mathrm{NH}_{3}$ & 352.87 & 0.476 \\
\hline Dust & PM2.5 & 119.61 & 0.161 \\
\hline Bio.mater.Incineration & PM2.5 & 61.92 & 0.084 \\
\hline Road vehicles & PM2.5 & 52.07 & 0.070 \\
\hline Non-road engines & PM2.5 & 30.97 & 0.042 \\
\hline Road vehicles & $\mathrm{NO}_{\mathrm{x}}$ & 22.22 & 0.030 \\
\hline Combustion (Energy) & $\mathrm{SO}_{\mathrm{x}}$ & 20.54 & 0.028 \\
\hline Combustion (Indust.) & PM2.5 & 17.99 & 0.024 \\
\hline Area emissions & $\mathrm{NH}_{3}$ & 7.19 & 0.010 \\
\hline Combustion (Energy) & PM2.5 & 6.83 & 0.009 \\
\hline Non-road engines & $\mathrm{NO}_{x}$ & 6.16 & 0.008 \\
\hline Combustion (Non-indust.) & $\mathrm{SO}_{\mathrm{x}}$ & 5.64 & 0.008 \\
\hline Combustion (Non-indust.) & PM2.5 & 5.36 & 0.007 \\
\hline Road vehicles & $\mathrm{NH}_{3}$ & 4.89 & 0.007 \\
\hline Combustion (Non-indust.) & $\mathrm{NO}_{x}$ & 4.43 & 0.006 \\
\hline Combustion (Indust.) & $\mathrm{SO}_{\mathrm{x}}$ & 4.31 & 0.006 \\
\hline Combustion (Energy) & $\mathrm{NO}_{x}$ & 3.02 & 0.004 \\
\hline Waste treatment & $\mathrm{SO}_{\mathrm{x}}$ & 2.85 & 0.004 \\
\hline Combustion (Indust.) & $\mathrm{NO}_{x}$ & 2.36 & 0.003 \\
\hline Waste treatment & PM2.5 & 1.93 & 0.003 \\
\hline Waste treatment & $\mathrm{NO}_{x}$ & 1.60 & 0.002 \\
\hline Area emissions & PM2.5 & 1.27 & 0.002 \\
\hline Indust.Process & $\mathrm{SO}_{\mathrm{x}}$ & 1.12 & 0.002 \\
\hline Indust.Process & PM2.5 & 0.98 & 0.001 \\
\hline Combustion (Non-indust.) & $\mathrm{NH}_{3}$ & 0.74 & 0.001 \\
\hline Bio.mater.Incineration & $\mathrm{NO}_{x}$ & 0.56 & 0.001 \\
\hline Indust.Process & $\mathrm{NH}_{3}$ & 0.54 & 0.001 \\
\hline Indust.Process & $\mathrm{NO}_{x}$ & 0.31 & 0.000 \\
\hline Combustion (Indust.) & $\mathrm{NH}_{3}$ & 0.28 & 0.000 \\
\hline Non-road engines & $\mathrm{SO}_{x}$ & 0.20 & 0.000 \\
\hline Non-road engines & $\mathrm{NH}_{3}$ & 0.09 & 0.000 \\
\hline Road vehicles & $\mathrm{SO}_{\mathrm{x}}$ & 0.06 & 0.000 \\
\hline Bio.mater.Incineration & $\mathrm{SO}_{x}$ & 0.03 & 0.000 \\
\hline Waste treatment & $\mathrm{NH}_{3}$ & 0.02 & 0.000 \\
\hline Bio.mater.Incineration & $\mathrm{NH}_{3}$ & 0.01 & 0.000 \\
\hline Area emissions & $\mathrm{NO}_{x}$ & 0.01 & 0.000 \\
\hline Total & & 740.99 & 1.000 \\
\hline
\end{tabular}

하여 각 배출원별 DALY를 산정하였다. 본 연구에서는 『배 출원 대분류』자료만 사용하였다.

전주시의 경우 Table 6에 나타낸 바와 같이 가장 높은 $\mathrm{DALY}$ 를 나타내는 대기오염물질 배출원 및 배출물질은 “비 산먼지(Dust)의 PM2.5"로서 549.85 DALY이며 총 DALY의 $20.0 \%$ 를 차지한다. 뒤이어 "농업(Agriculture)의 $\mathrm{NH}_{3}$ ”가 406.12 $\mathrm{DALY}$ 로서 $14.8 \%$, “도로이동오염원(Road vehicles)의 PM2.5" 가 $12.8 \%$, "비도로 이동오염원(Non-road engines)의 PM2.5"
Table 8. Contribution of emission source \& pollutant on the DALY of Changwon due to intake of primary and secondary fine particulates.

\begin{tabular}{|c|c|c|c|}
\hline Emission source & Pollutant & DALY & Ratio \\
\hline Combustion (Indust.) & PM2.5 & 1352.46 & 0.326 \\
\hline Non-road engines & PM2.5 & 526.64 & 0.127 \\
\hline Dust & PM2.5 & 416.49 & 0.100 \\
\hline Road vehicles & PM2.5 & 322.84 & 0.078 \\
\hline Agricultural & $\mathrm{NH}_{3}$ & 259.89 & 0.063 \\
\hline Bio.mater.Incineration & PM2.5 & 185.06 & 0.045 \\
\hline Non-road engines & $\mathrm{SO}_{x}$ & 157.70 & 0.038 \\
\hline Road vehicles & $\mathrm{NO}_{\mathrm{x}}$ & 149.02 & 0.036 \\
\hline Combustion (Indust.) & $\mathrm{SO}_{x}$ & 127.67 & 0.031 \\
\hline Non-road engines & $\mathrm{NO}_{x}$ & 121.26 & 0.029 \\
\hline Indust.Process & PM2.5 & 97.84 & 0.024 \\
\hline Indust.Process & $\mathrm{SO}_{x}$ & 84.06 & 0.020 \\
\hline Combustion (Non-indust.) & $\mathrm{SO}_{x}$ & 76.76 & 0.018 \\
\hline Area emissions & $\mathrm{NH}_{3}$ & 60.40 & 0.015 \\
\hline Road vehicles & $\mathrm{NH}_{3}$ & 53.49 & 0.013 \\
\hline Combustion (Indust.) & $\mathrm{NO}_{x}$ & 43.92 & 0.011 \\
\hline Combustion (Non-indust.) & $\mathrm{NO}_{x}$ & 41.29 & 0.010 \\
\hline Combustion (Non-indust.) & PM2.5 & 28.08 & 0.007 \\
\hline Indust.Process & $\mathrm{NO}_{x}$ & 9.95 & 0.002 \\
\hline Combustion (Non-indust.) & $\mathrm{NH}_{3}$ & 7.79 & 0.002 \\
\hline Area emissions & PM2.5 & 6.79 & 0.002 \\
\hline Waste treatment & $\mathrm{SO}_{x}$ & 6.52 & 0.002 \\
\hline Waste treatment & PM2.5 & 5.63 & 0.001 \\
\hline Waste treatment & $\mathrm{NO}_{x}$ & 3.96 & 0.001 \\
\hline Combustion (Indust.) & $\mathrm{NH}_{3}$ & 3.79 & 0.001 \\
\hline Bio.mater.Incineration & $\mathrm{NO}_{x}$ & 0.73 & 0.000 \\
\hline Road vehicles & $\mathrm{SO}_{x}$ & 0.47 & 0.000 \\
\hline Non-road engines & $\mathrm{NH}_{3}$ & 0.29 & 0.000 \\
\hline Bio.mater.Incineration & $\mathrm{SO}_{\mathrm{x}}$ & 0.08 & 0.000 \\
\hline Waste treatment & $\mathrm{NH}_{3}$ & 0.08 & 0.000 \\
\hline Area emissions & $\mathrm{NO}_{x}$ & 0.05 & 0.000 \\
\hline Bio.mater.Incineration & $\mathrm{NH}_{3}$ & 0.02 & 0.000 \\
\hline Total & & 4151.01 & 1.000 \\
\hline
\end{tabular}

가 $11.4 \%$, “생물성 연소(Biomaterial incineration)의 PM2.5" 가 $11.2 \%$ 를 차지하였다. 따라서 전주시 PM2.5에 의한 지역 건강영향을 감소시키기 위해 “비산먼지”(도로 재비산먼지, 건설공사, 나대지, 축산활동, 비포장도로 비산먼지 등), "도 로이동오염원”(승용차, 택시, 화물차, 이륜차 등) 및 “비도로 이동오염원"(농업기계, 건설장비, 철도) 발생원 등에서 배출 하는 1차 PM2.5 직접 배출 저감 대책과 2차 PM2.5 생성을 야기하는 “농업”(비료사용농경지, 분뇨관리 등)분야 $\mathrm{NH}_{3}$ 배 출저감 대책이 아울러 필요함을 시사한다.

익산시의 경우(Table 7 참조) 가장 높은 DALY를 나타내 는 대기오염물질 배출원 및 배출물질은 "농업의 $\mathrm{NH}_{3}$ "로서 $352.87 \mathrm{DALY}$ 이며 익산시 총 DALY의 $47.6 \%$ 를 차지한다. 
뒤이어 "비산먼지의 PM2.5"가 119.61 DALY로서 $16.1 \%$, “생물성연소의 PM2.5"가 8.4\%, "도로이동오염원의 PM2.5" 가 $7.0 \%$, “비도로 이동오염원의 PM2.5”가 $4.2 \%$ 를 차지하 는 것으로 나타났다. 따라서 익산시는 지역 내 PM2.5에 의 한 건강영향을 감소시키기 위해 “농업(비료사용농경지, 분 뇨관리 등)”발생원의 $\mathrm{NH}_{3}$ 배출저감 대책이 절실히 필요하 며, "비산먼지(도로 재비산먼지, 건설공사, 나태대지, 축산 활동, 비포장도로 비산먼지 등)”, “생물성 연소(노천소각, 농업잔재물 소각, 고기 및 생선구이, 목재난로 및 보일러, 아궁이 등)" 및 “도로이동오염원”발생원 등에서 발생하는 $\mathrm{PM} 2.5$ 배출 저감 대책이 필요한 것으로 나타났다.

Table 8의 창원시의 경우 가장 높은 DALY를 나타내는 대기 오염물질 배출원 및 배출물질은 “제조업연소(Combustion (industry))의 PM2.5"로서 1,352 DALY이며 창원시 총 DALY 의 $32.6 \%$ 를 차지한다. 뒤이어 "비도로 이동오염원의 PM2.5" 가 $12.7 \%$, “비산먼지의 PM2.5"가 $10.0 \%$, “도로이동오염원의 $\mathrm{PM} 2.5$ "가 7.8\%, "농업의 $\mathrm{NH}_{3}$ " 6.3\%를 차지하는 것으로 나타 났다. 따라서 창원시는 지역 내 PM2.5에 의한 건강영향을 감소시키기 위해 “제조업 연소”발생원의 PM2.5 직접 배출 저감 대책이 우선적으로 필요하며, “비도로 이동오염원”(농 업기계, 건설장비, 철도), “비산먼지(도로 재비산먼지, 건설공 사, 나태대지, 축산활동, 비포장도로 비산먼지 등)", “도로이 동오염원" 등에서 발생하는 PM2.5 배출 저감에 대한 대책이 필요함을 시사한다.

\section{6. 토의 및 시사점}

두 방법에 의한 건강영향 정량화에 가장 영향을 미치는 인자를 살펴보았다. 첫째, PM2.5 농도에 노출되는 건강영 향을 직접 산정하는 방법은 PM2.5 연평균 농도에 의해 결 과가 결정되었다. PM2.5 연평균 농도가 가장 높은 익산시 $\left(40 \mu \mathrm{g} / \mathrm{m}^{3}\right)$ 의 DALY (1000명 당)가 상대적으로 가장 높게 얻어진다. 그러나 두 번째 방법인 LCIA방법에서는 "대기 오염물질 배출량( $\left.\mathrm{PM} 2.5, \mathrm{SO}_{\mathrm{x}}, \mathrm{NO}_{\mathrm{x}}, \mathrm{NH}_{3}\right)$ ", "대기환경(혼합 고, 체류시간)"과 “노출정도(인구밀도)" 등 다양한 인자가 영향을 주고 있다. 예를 들어, 전주시는 창원시에 비해 대 기오염물질 배출량은 훨씬 적지만 높은 흡입률을 나타내어 건강영향 DALY ( 1000 명 당)가 상대적으로 가장 높게 산정 되었다.

본 연구에서 두 가지 방법으로 PM2.5 흡입에 따른 건강 영향을 정량화하였다. 각 지역 PM2.5 농도에 노출되는 건 강영향을 직접 산정한 결과, 전주 $25.44 \mathrm{DALY} / 1000$ 명, 익 산 $35.03 \mathrm{DALY} / 1000$ 명, 창원 $22.24 \mathrm{DALY}$ 이었다. 반면 대 기오염물질 배출량자료, 노출계수 및 건강영향 계수를 활용 하는 LCIA방법으로 산정한 결과는 전주 4.22 DALY/1000명, 익산 $2.50 \mathrm{DALY} / 1000$ 명, 창원 $3.99 \mathrm{DALY} / 1000$ 명이었다. 두 방법에 의한 건강영향이 각각 다르게 산출되었다. 세 도 시의 DALY 수치 순서 및 절대적 값에 있어 큰 차이가 발 생한다.
본 연구에서는 두 가지 방법에 의한 건강영향 결과 차이 는 외부로부터의 대기오염물질 유입으로 보고 있다. 예를 들어 익산의 경우, 지역 배출량에 근거한 건강영향은 2.5 $\mathrm{DALY} / 1000$ 명에 불과하지만 실제로 PM2.5 농도에 노출되 는 건강영향은 $35.03 \mathrm{DALY} / 1000$ 명이었다. 이는 익산시 공 간적 범위에서 발생하는 1차 및 2 차 PM2.5 물질로 인한 건강영향은 적으나 익산시 이외에서 유입되는 1차 및 2 차 PM2.5 물질에 의한 건강영향이 월등히 많음을 시사한다. 전주 및 창원의 경우도 지역 배출량에 의해 산정한 DALY 가 실제 PM2.5 농도에 의한 DALY와 큰 차이를 보이는 이 유도 각 시의 공간적 범위 이외에서 유입되는 물질에 의해 건강영향이 지대한 영향을 받고 있음을 시사한다. 또한 두 가지 방법에 의한 건강영향이 큰 차이를 나타내는 데서 유 추해 볼 수 있는 점은 대기오염물질 배출량 자료의 불확실 성이다. 지역 대기오염 배출량 자료가 실제보다 적게 예측 되어 있을 수도 있다.

첫 번째 PM2.5 농도에 반응하는 건강영향 정량화방법은 지역과 상관없이 PM2.5 농도에 의해서만 인체영향이 정량 화되므로 각 도시의 특징을 전혀 반영하지 못한다. 지역 내 구체적 대책 수립을 위한 정보를 줄 수 없는 한계가 있다. 반면, 전과정(Life cycle) 개념에 기반한 LCIA방법은 인간 건강에 최종적으로 영향을 미치는 각 대기오염물질 및 배 출원을 확인할 수 있으므로 미세먼지 우선관리 대책 수립 의 기초자료를 도출할 수 있게 해 준다. 익산시의 경우를 보더라도 1차 PM2.5 직접 배출에 의한 인체영향보다 오히 려 $\mathrm{NH}_{3}$ 가 형성하는 2 차 $\mathrm{PM} 2.5$ 가 더욱 인체에 영향을 미칠 수 있는 점이다. 창원시의 경우 지역 대기오염물질 배출량 이 타 시보다 월등이 많지만 실질적으로 거주민들이 흡입 하는 정도(흡입률)가 낮아 인체영향이 상쇄되는 점 등 다 양한 정보를 줄 수 있다. 앞으로 우리나라의 건강영향 계수 개발과 거동 및 노출인자 연구 등 보다 체계적인 LCIA 방 법 연구가 필요하다.

\section{4. 결론}

본 연구에서는 미세먼지 흡입으로 인해 발생할 수 있는 심 폐질환 및 폐암 등 건강영향을 장애보정손실년수(DALY)로 정량화하는 두 가지 방법을 사용하였다. 첫 번째 방법은 PM2.5 농도에 반응하는 건강영향을 직접 산정하며 두 번째는 대기오염물질 배출량 자료, 노출계수 및 건강영향 계수 등을 활용하는 전과정평가의 환경영향평가방법(LCIA)이었으며 그 결과는 다음과 같다.

1. 첫 번째 방법에 의해 전주시, 익산시 및 창원시 30 세 이상 연령별 자료, $\mathrm{CRF}, \mathrm{SF}$ 및 각 지역 미세먼지 PM2.5 농도를 바탕으로 심폐질환 및 폐암에 대한 DALY는 전주 시 10,504 , 익산시 6,657 , 창원시 15,154 로 산정되었다. 인구수 1000 명당 DALY를 재산정한 결과는 전주 25.44 $\mathrm{DALY} / 1000$ 명, 익산 $35.03 \mathrm{DALY} / 1000$ 명, 창원 22.24 


\section{DALY이었다.}

2. 두 번째 LCIA방법에 의한 1차 및 2차 PM2.5 물질의 건강영향, $\mathrm{DALY}$ 기여도에서 전주시는 1 차 PM2.5 직 접 배출물질에 의한 기여도 $(60 \%)$ 가 가장 높게 나타났 고, 익산시는 $\mathrm{NH}_{3}$ 로 인해 형성되는 2차 $\mathrm{PM} 2.5$ 에 의한 DALY기여도 $(49 \%)$ 가 가장 높은 특징을 나타냈다. 창 원시는 1차 PM2.5 직접 배출에 의한 DALY기여도(71\%) 가 가장 높았다.

3. 전주시 DALY에 가장 기여하는 대기오염물질 배출원 및 배출물질은 “비산먼지의 PM2.5"로서 총 DALY의 $21.1 \%$ 를 차지하고, "농업의 $\mathrm{NH}_{3}$ " $13.6 \%$, “도로이동오염원의 PM2.5" $13.5 \%$, "비도로이동오염원의 PM2.5" $12.0 \%$, “생 물성연소의 PM2.5" $11.9 \%$ 순이었다.

4. 익산시 DALY에 가장 기여하는 대기오염물질 배출원 및 배출물질은 "농업의 $\mathrm{NH}_{3}$ "로서 352.87 DALY이며 총 DALY의 $47.6 \%$ 를 차지하고, "비산먼지의 PM2.5" $16.1 \%$, “생물성연소의 PM2.5” 8.4\%, “도로이동오염원 의 PM2.5" $7.0 \%$ 순이었다.

5. 창원시 DALY에 가장 기여하는 대기오염물질 배출원 및 배출물질은 “제조업연소의 PM2.5”로서 총 $\mathrm{DALY}$ 의 $32.6 \%$ 를 차지하고, "비도로 이동오염원의 PM2.5" $12.7 \%$, "비산먼지의 PM 2.5 " $10.0 \%$, “도로이동오염원 의 $\mathrm{PM} 2.5$ " $7.8 \%$, "농업의 $\mathrm{NH}_{3}$ " $6.3 \%$ 순이다.

6. PM2.5 농도에 노출되는 건강영향결과와 LCIA 건강영 향결과의 큰 차이는 각 시공간적 범위 내에서 발생하 는 PM2.5 물질보다 시 경계 밖에서 유입되는 1차 및 2차 PM2.5 물질에 의해 지역 건강이 더욱 영향이 받을 수 있음을 시사한다. 또한 대기오염물질 배출량이 실제 보다 적게 산정되었을 수도 있음을 시사한다.

\section{Acknowledgments}

본 연구는 환경부 지원 전북녹색환경지원센터와 경남녹색 환경지원센터의 공동연구사업으로 수행되었습니다.

\section{References}

1. C. A. Pope, R. T. Burnett, M. J. Thun, E. E. Calle, D. Krewski, K. Ito, G. D. Thurston, Lung cancer, cardiopulmonary mortality, and long-term exposure to fine particulate air pollution, JAMA, 287(9), 1132-1141(2002).

2. World Health Organization, Ambient Air Pollution: A Global Assessment of Exposure and Burden of Disease, WHO, Geneva, Switzerland, pp. 13-39(2016).

3. G. Hoek, R. M. Krishnan, R. Beelen, A. Peters, B. Ostro, B. Brunekreef, J. D. Kaufman, Long-term air pollution exposure and cardio-respiratory mortality: a review, Environ.
Health, 12(1), 43-59(2013).

4. N. K. Moon, J. S. Ha, J. H. Seo, Calculation of years of life lost and PM2.5 concentration due to the National Industrial Complex, Environmental Forum, 22(9), 1-14(2018).

5. J. Kim, Assessment and estimation of particulate matter formation potential and respiratory effects from air emission matters in industrial sectors and cities/regions, J. Korean Soc. Environ. Eng., 39(4), 220-228(2017).

6. R. Zelm, M. A. J. Huijbregts, H. A. Hollander, H. A. Jaarsveld, F. J. Sauter, J. Struijs, H. J. Wijnen, D. Meent, European characterization factors for human health damage of PM10 and ozone in life cycle impact assessment, Atmos. Environ., 42(3), 441-453(2008).

7. J. C. Bare, TRACI: The tool for the reduction and assessment of chemical and other environmental impacts, J. Ind. Ecol., 6(3-4), 49-78(2002).

8. S. Humbert, J. D. Marshall, S. Shaked, J. V. Spadaro, Y. Nishioka, P. Preiss, T. E. McKone, A. Horvath, O. Jolliet, Intake fraction for particulate matter: recommendations for life cycle impact assessment, Environ. Sci. Technol., 45(11), 4808-4816(2011).

9. C. J. Gronlund, S. Humbert, S. Shaked, M. S. O’Neill, O. Jolliet, Characterizing the burden of disease of particulate matter for life cycle assessment, Air Qual. Atmos. Health, 8(1), 29-46(2015).

10. Jeonbuk Green Center, Analysis of Fine Particulates in Jeonbuk and Its Control Strategies, Jeonbuk Green Center, Jeonju, Korea(2019).

11. J. S. Apte, E. Bombrun, J. D. Marshall, W. W. Nazaroff, Global intraurban intake fractions for primary air pollutants from vehicles and other distributed sources, Environ. Sci. Technol., 46(6), 3415-23(2012).

12. P. Fantke, O. Jolliet, J. S. Apte, N. Hodas, J. Evans, C. J. Weschler, K. S. Stylianou, M. Jantunen, T. E. McKone, Characterizing aggregated exposure to primary particulate matter: Recommended intake fractions for indoor and outdoor sources, Environ. Sci. Technol., 51(16), 9089-9100 (2017).

13. Ministry of Environment (MOE), Korean Exposure Factors Handbook, Gwachun, Korea, pp. 42-172(2007).

14. Korean Statistical Information Service (KOSIS), http://kosis.kr/eng/

15. H. Jin, Study on the Vertical Atmospheric Structure and Development Mixed Layer over Jeonju Region, M.S. Thesis, Pusan National University, Korea(2005).

16. J. H. Seinfeld, S. N. Pandis, Atmospheric Chemistry and Physics: From Air Pollution to Climate Change, 2nd ed., John Wiley and Sons, New York, USA (2006).

17. National Institute of Environmental Research (NIER), Annual Report of Air Quality Korea 2015, Incheon, Korea, pp. 184-201(2016).

18. National Air Pollutants Emission Service, http://airemiss.nier.go. $\mathrm{kr} / \mathrm{mbshome} / \mathrm{mbs} /$ airemiss/index.do 